\title{
Treatment and outcome in medication overuse headache patients
}

\author{
D Mitsikostas, I Deligianni* \\ From The European Headache and Migraine Trust International Congress \\ London, UK. 20-23 September 2012
}

\section{Background}

Medication overuse headache $(\mathrm{MOH})$ is a frequent condition in headache centers with elusive management and outcomes. Aim: to present the pharmaceutical treatment and outcome of $\mathrm{MOH}$ patients from the outpatient Headache Clinic of the Athens Naval Hospital.

\section{Methods}

This is an open, retrospective, single center observational study. The electronic files of patients with $\mathrm{MOH}$ of the Athens Naval Hospital Out-Patient Headache Clinic were reviewed to assess the outcome.

\section{Results}

One hundred forty six patients ( 29 males and 117 females) with $\mathrm{MOH}$ were evaluated (mean age $38.5 \pm 12.7$ years; mean body mass index $26.1 \pm 4.44)$. Patients overused triptans (38.9\%), analgesics (61.1\%), NDAIDs (48.4\%), codein plus paracetamol (77.6\%), bezodiazepines (2.3\%), or ergotamine (17.5\%). Scores for Hamilton scale for anxiety and depression were $23.9 \pm 5.6$ and $18.8 \pm 6.5$, respectively. Prophylactic treatment consisted of naproxen $1000 \mathrm{mg}$ (plus gastroproplylaxis), SNRI (venlafaxine $150-300 \mathrm{mg} / \mathrm{d}$, or mirtazapine $45-90 \mathrm{mg} / \mathrm{d}$ ) and one of three agents: propranolol $(160-320 \mathrm{mg} / \mathrm{d})$, topiramate $(100 \mathrm{mg})$ or valproate $(500-1500 \mathrm{mg} / \mathrm{d})$. In cases of anxiety disorder comorbidity (HAM-A score $>18$ ) prazepam was added (10-20mg/d). All patients were advised to withdraw immediately the substance overused. After one to three months treatment $37 \%$ and $45.6 \%$ of patients reported a greater of $50 \%$ or $75 \%$ decrease of days with headache per month, respectively. The $17.3 \%$ of the patient population did not respond to treatment.

\footnotetext{
Athens Naval Hospital, Greece
}

\section{SpringerOpen $^{\circ}$}

\section{Conclusion}

Immediate withdraw of substance overused combined with a strong prophylactic treatment, which included naproxen, SNRIs and preventative antimigraine agents is efficient to decrease headache impact in most patients with $\mathrm{MOH}$.

Published: 21 February 2013

doi:10.1186/1129-2377-14-S1-P180

Cite this article as: Mitsikostas and Deligianni: Treatment and outcome in medication overuse headache patients. The Journal of Headache and Pain 2013 14(Suppl 1):P180.
Submit your manuscript to a SpringerOpen ${ }^{\bullet}$ journal and benefit from:

- Convenient online submission

- Rigorous peer review

- Immediate publication on acceptance

- Open access: articles freely available online

- High visibility within the field

- Retaining the copyright to your article

Submit your next manuscript at $>$ springeropen.com 